\title{
Safety Evaluation, in Vitro and in Vivo Antioxidant Activity of the Flavonoid-Rich Extract from Maydis stigma
}

\author{
Ke-Zheng Peng ${ }^{1,2}$, Xiudong Yang ${ }^{1}$, Hong-Li Zhou ${ }^{1, *}$ and Shu-Xia Pan ${ }^{3}$ \\ Received: 29 October 2015 ; Accepted: 7 December 2015 ; Published: 10 December 2015 \\ Academic Editor: Christopher W. K. Lam \\ 1 College of Chemical and Pharmaceutical Engineering, Jilin Institute of Chemical Technology, \\ Jilin 132022, China; pkz1994.3.1@163.com (K.-Z.P.); yangwt_1981@163.com (X.Y.) \\ 2 College of pharmacy, Zhengzhou University, Zhengzhou 450001, China \\ 3 Department of Mathematics, School of Public Health, Jilin Medical College, Jilin 132013, China; \\ pan4652405@163.com \\ * Correspondence: zhl67@126.com; Tel.: +86-432-6218-5246; Fax: +86-432-6309-3625
}

\begin{abstract}
This study aimed to assess the acute toxicity and safety of flavonoid-rich extract from Maydis stigma (FMS) in mice. The in vitro antioxidant activity of FMS was determined by 1,1-diphenyl-2-picrylhydrazyl (DPPH) and 2,2'-azinobis-(3-ethyl-benzthiazoline-6-sulphonate) (ABTS) scavenging assays. Furthermore, the in vivo antioxidant of FMS against ethanol-induced oxidative damage in mice was determined by analysis of the serum total superoxide dismutase (T-SOD) activity, malondialdehyde (MDA) content, liver tissue glutathione (GSH) content, and protein carbonyl (PC) content in liver tissue. The oral administration of FMS at doses of $30 \mathrm{~g} / \mathrm{kg}$ did not cause death in mice, and there were no significant biologically adverse effects in mice. These results indicated that the median lethal dose $\left(\mathrm{LD}_{50}\right)$ is higher than this dose. The $\mathrm{IC}_{50}$ values of FMS for the DPPH and ABTS scavenging activity were 50.73 and $0.23 \mathrm{mg} / \mathrm{mL}$, respectively. Meanwhile, FMS could significantly enhance T-SOD activity, reduce MDA content in the serum, increase GSH content, and decrease PC content in the liver tissue at the tested doses $(25,50,100,200 \mathrm{mg} / \mathrm{kg}$. day). These results indicate that FMS can be generally regarded as safe and used potentially as a bioactive source of natural antioxidants.
\end{abstract}

Keywords: flavonoids; Maydis stigma; acute toxicity; antioxidant activity

\section{Introduction}

Maize is the world's third most widely grown crop [1], which has not only been used as food and animal feed for thousands of years, but also as industrial material for producing starches, oils, and ethanol [2]. Maydis stigma is the stigma of the maize female flower. It was reported to contain various biological active compounds, such as polysaccharides [3], flavonoids [4], steroids, tannins [5], saponins, $\mathrm{Ca}, \mathrm{K}, \mathrm{Mg}$ and $\mathrm{Na}$ salts, amino acids, organic acids, etc. Based on its chemical composition, Maydis stigma has many pharmacological activities, like antipyretic choleretic [6], antioxidant $[7,8]$, antibacterial [9], anti-inflammation [10], anti-depressant [11], anti-fatigue [12], anti-diabetic [13], etc. Meanwhile, because of its low price and high medicinal value, it is attracting increasing attention of researchers.

It has been reported that the potential pharmacological activities of Maydis stigma are related to the bioactive constituents of the plant such as flavonoids [14]. Flavonoids exist widely in plants, and many studies have indicated that they can effectively scavenge reactive free radicals to protect the cells against free radical oxidation damage $[15,16]$. For instance, the flavonoids extracted from 
different plants, such as blueberry [17], calamondin [18], saffron [19], and Radix scutellariae [20] were demonstrated to have high antioxidant activity.

Meanwhile, many researches have described that flavonoids of Maydis stigma possess a potent antioxidant activity in vitro [21,22]. Besides, it has been suggested that flavonoids from Maydis stigma inhibit lipid peroxidation, increase anti-oxidant enzyme levels, and improve the exercise tolerance of mice [23]. Therefore, it is important to study the acute toxicity and safety of the purified flavonoids from M. stigma as well as their antioxidant activity.

However, there are few reports on the toxicological aspects of the flavonoids extracted from M. stigma so far. The acute toxicity test is the most basic method of the testing stage of the toxicology safety assessment, and plays a key role in chemical toxicity assessment [24]. Therefore, further studies on the acute toxicity of flavonoids extracted from M. stigma are essential to ensure its safe application.

The aim of this study is to evaluate the acute toxicity, safety, and antioxidant activity of the flavonoids extracted from M. stigma (FMS) by the following tests of oral acute toxicity in mice, in vitro antioxidant activity, and in vivo antioxidant activity in mice.

\section{Results and Discussion}

\subsection{Acute Toxicity in Mice}

\subsubsection{General Clinical Signs}

During a 14-day observation period, there were no abnormal signs in any of the groups, which included addition of body weight, as well as food and water consumption. Besides, the solutions of FMS at the dose of $30 \mathrm{~g} / \mathrm{kg}$ did not cause the death of male and female mice over 14 days. The results revealed that FMS is non-toxic. Therefore, the results indicated that the oral lethal dose $\left(\mathrm{LD}_{50}\right)$ value for oral administration of FMS in male and female mice is higher than $30 \mathrm{~g} / \mathrm{kg}$.

Table 1 and Figure 1 show the body weights and food consumption of mice in the acute toxicity test, respectively. The body weight gain and the food consumption of the experimented group mice were similar to the control group and there were no significant differences between the two groups $(p>0.05)$. The results showed that, compared to the control group, there were no significant effects of FMS on body weight and food consumption of male and female mice at a dose of $30 \mathrm{~g} / \mathrm{kg}$.

Table 1. Body weights of mice in the acute toxicity test.

\begin{tabular}{cccc}
\hline Group & 0 day Weight $(\mathbf{g})$ & 14 day Weight $(\mathbf{g})$ & Addition of Weight $(\mathbf{g})$ \\
\hline Male control group & $21.95 \pm 2.35$ & $25.35 \pm 3.04$ & $3.40 \pm 1.08$ \\
Male experimented group & $21.63 \pm 1.98$ & $25.27 \pm 2.76$ & $3.64 \pm 1.56$ \\
Female control group & $18.05 \pm 1.75$ & $21.88 \pm 2.09$ & $3.83 \pm 0.95$ \\
Female experimented group & $18.33 \pm 2.56$ & $22.13 \pm 2.82$ & $3.80 \pm 1.12$ \\
\hline
\end{tabular}

Values are mean \pm SD for 5 mice in each group. Time (day).

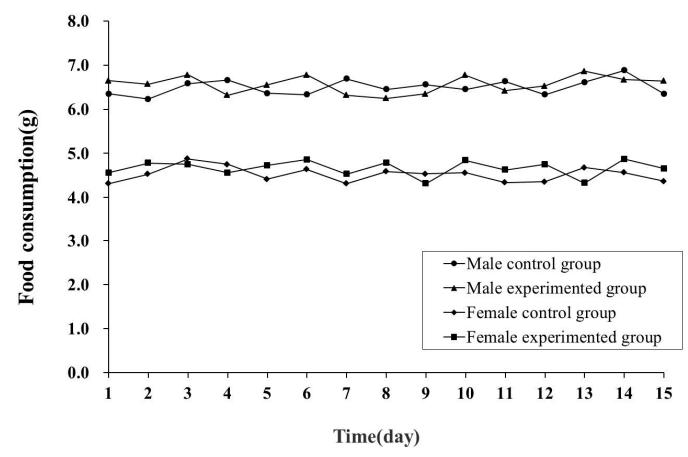

Figure 1. Food consumption of mice in the acute toxicity test. 
The organ coefficient is the ratio of the organ weight to the body weight of the experimental animal, which is commonly used in toxicological evaluation of medicines. With organ damage caused by poisoning, the organ's weight will change. So the organ coefficient can reflect the pathological changes caused by poisoning [25]. Table 2 showed the organ coefficient of mice in the acute toxicity test. As shown in the table, the organ coefficients of the experimented group mice were similar to the control group and there were no significant differences $(p>0.05)$. In addition, after 14 days, no organs were observed to have obvious lesions in the mice of any of the groups. Therefore, there were no obvious pathological changes in the main organs (heart, liver, spleen, lung, kidney, thymus, brain, bladder, uterus, testis, epididymis, seminal vesicle) of male and female mice at a dose of $30 \mathrm{~g} / \mathrm{kg}$.

Table 2. Organ coefficient of mice in the acute toxicity test $(\mathrm{mg} / \mathrm{g})$.

\begin{tabular}{ccccc}
\hline & $\begin{array}{c}\text { Male Control } \\
\text { Group }\end{array}$ & $\begin{array}{c}\text { Male Experimented } \\
\text { Group }\end{array}$ & $\begin{array}{c}\text { Female Control } \\
\text { Group }\end{array}$ & $\begin{array}{c}\text { Female Experimented } \\
\text { Group }\end{array}$ \\
\hline Heart & $9.18 \pm 1.57$ & $8.84 \pm 1.39$ & $7.55 \pm 0.75$ & $7.01 \pm 0.98$ \\
Liver & $92.33 \pm 2.62$ & $94.28 \pm 3.51$ & $77.15 \pm 2.33$ & $78.91 \pm 3.06$ \\
Spleen & $5.15 \pm 1.17$ & $5.29 \pm 2.01$ & $4.88 \pm 0.95$ & $4.60 \pm 0.82$ \\
Lung & $9.72 \pm 1.58$ & $9.93 \pm 1.35$ & $7.99 \pm 1.14$ & $7.91 \pm 1.85$ \\
Kidney & $25.70 \pm 2.37$ & $25.46 \pm 1.99$ & $17.82 \pm 1.13$ & $18.29 \pm 1.54$ \\
Thymus & $2.33 \pm 0.75$ & $2.68 \pm 0.93$ & $2.01 \pm 0.50$ & $2.16 \pm 0.37$ \\
Brain & $10.43 \pm 2.54$ & $9.90 \pm 1.35$ & $8.57 \pm 1.18$ & $8.26 \pm 1.05$ \\
Bladder & $1.25 \pm 0.20$ & $1.08 \pm 0.32$ & $0.86 \pm 0.21$ & $0.77 \pm 0.31$ \\
Testis (Uterus) & $6.22 \pm 0.79$ & $6.32 \pm 0.63$ & $5.14 \pm 1.83$ & $5.57 \pm 1.49$ \\
Epididymis & $2.03 \pm 1.24$ & $2.17 \pm 1.05$ & & \\
Seminal vesicle & $4.84 \pm 1.38$ & $5.03 \pm 1.60$ & & \\
\hline
\end{tabular}

Values are mean \pm SD for 5 mice in each group.

\subsubsection{Serum Biochemical Parameters}

Table 3 presents the serum biochemical parameters of mice in the acute toxicity assay. In general, there were no biologically significant adverse effects. Compared to the control group, FMS at doses of $30 \mathrm{~g} / \mathrm{kg}$ did not induce significant changes of the biochemical parameters (glucose (GLU), alkaline phosphatase (ALP), alanine aminotransferase (ALT), aspartate aminotransferase (AST).

In summary, the mice in the experimented groups were orally administered with FMS and a dose up to $30 \mathrm{~g} / \mathrm{kg}$ did not cause any adverse effects in mice when compared to the control group.

Table 3. Serum biochemical parameters of mice in the acute toxicity test.

\begin{tabular}{ccccc}
\hline Group & $\begin{array}{c}\text { Male Control } \\
\text { Group }\end{array}$ & $\begin{array}{c}\text { Male Experimented } \\
\text { Group }\end{array}$ & $\begin{array}{c}\text { Female Control } \\
\text { Group }\end{array}$ & $\begin{array}{c}\text { Female } \\
\text { Experimented Group }\end{array}$ \\
\hline ALT (U/L) & $49.28 \pm 3.52$ & $51.72 \pm 4.13$ & $37.91 \pm 2.78$ & $35.82 \pm 3.03$ \\
AST (U/L) & $130.03 \pm 16.76$ & $125.63 \pm 20.27$ & $145.84 \pm 25.73$ & $148.01 \pm 18.46$ \\
ALP (U/L) & $118.31 \pm 21.54$ & $126.29 \pm 18.66$ & $106.51 \pm 22.03$ & $102.41 \pm 19.14$ \\
GLU (mmol/L) & $4.83 \pm 1.03$ & $4.22 \pm 0.98$ & $4.95 \pm 1.18$ & $5.12 \pm 1.32$ \\
\hline
\end{tabular}

Values are mean \pm SD for 5 mice in each group.

\subsection{In vitro Antioxidant Activity}

\subsubsection{DPPH Radical Scavenging Activity}

Figure 2 presents the DPPH scavenging activity of FMS, with vitamin $C$ used as positive control. FMS and vitamin $C$ were found to scavenge DPPH radical in a concentration-dependent manner. The DPPH radical scavenging ability of FMS was $25.72 \%-71.19 \%$ at concentrations $20.0-100.0 \mu \mathrm{g} / \mathrm{mL}$, respectively. Meanwhile, the DPPH radical scavenging ability of vitamin C was $4.74 \%-89.42 \%$ at concentrations $1.0-6.0 \mu \mathrm{g} / \mathrm{mL}$, respectively. $\mathrm{IC}_{50}$ values (calculated with the statistical programm 
SPSS 19.0) were $50.73 \pm 0.65 \mu \mathrm{g} / \mathrm{mL}$ and $3.86 \pm 0.18 \mu \mathrm{g} / \mathrm{mL}$ for FMS and vitamin C, respectively $(p<0.05)$. The results showed that FMS was demonstrated to have potent scavenging activity against the DPPH radical. However, the DPPH radical scavenging ability of FMS was weaker than that of vitamin C.

a

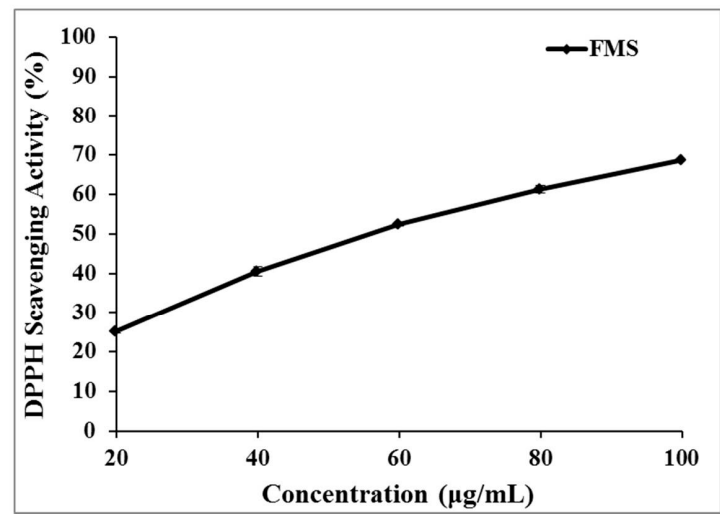

b

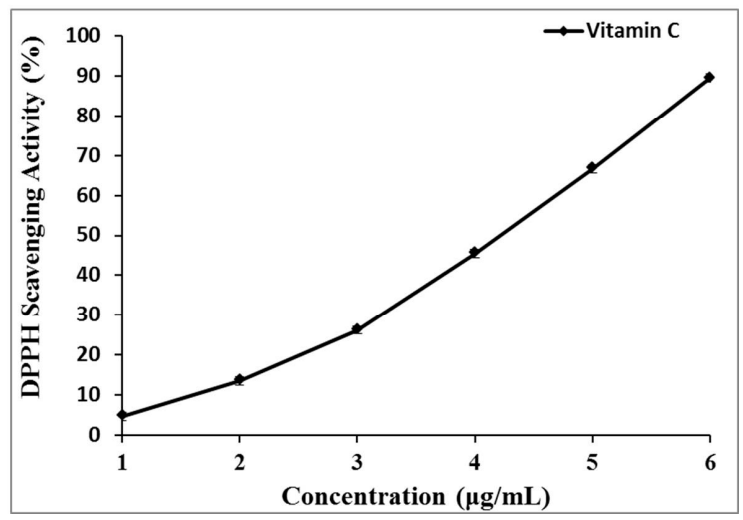

Figure 2. 1,1-Diphenyl-2-picrylhydrazyl (DPPH) radical scavenging ability of Maydis stigma (FMS)

(a) and vitamin C (b).

\subsubsection{ABTS Radical Scavenging Activity}

Figure 3 presents the ABTS radical scavenging ability of FMS and vitamin C. FMS reveals a dose-dependent response at concentrations from $0.1-1.0 \mathrm{mg} / \mathrm{mL}$. At the concentrations of $1.0-3.0 \mathrm{mg} / \mathrm{mL}$, the activities were not significant increased. Also at these concentrations, ABTS radical scavenging ability of FMS ranged from $22.75 \%-98.03 \%$ while the vitamin $C$ ranged from $99.31 \%-100.0 \%$. Additionally, IC 50 of FMS was $0.23 \pm 0.03 \mathrm{mg} / \mathrm{mL}(p<0.05)$. The results showed that FMS has a potent scavenging activity on ABTS radical at concentrations from $0.1-3.0 \mathrm{mg} / \mathrm{mL}$. The ABTS radical scavenging ability of FMS was slightly weaker than vitamin C.

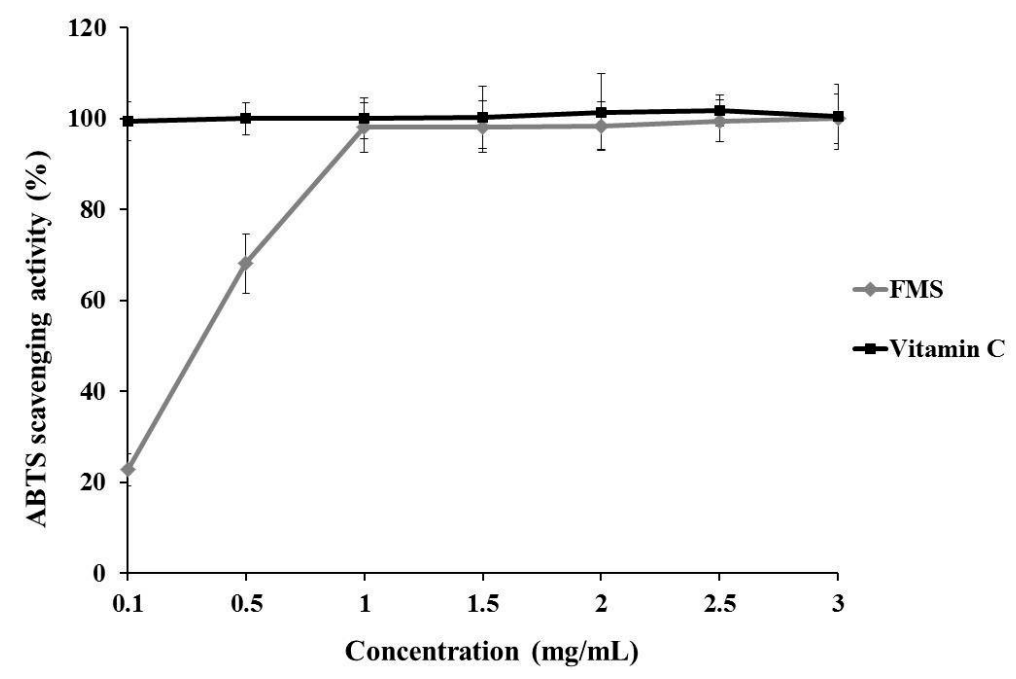

Figure 3. 2,2'-Azinobis-(3-ethyl-benzthiazoline-6-sulphonate) (ABTS) radical scavenging ability of FMS and vitamin $\mathrm{C}$. 


\subsection{In Vivo Antioxidant Activity in Mice}

\subsubsection{Effect of FMS on Organ Weights}

As shown in Table 4, the organ weights of the model group, positive control group, and dose groups were compared with the control group and there were no significant differences $(p>0.05)$. After the 30 day period, no organs were observed to have obvious lesions in mice of all groups. The results showed that, compared to the control group, there were no obvious pathological changes in the main organs of mice (liver, spleen, lung, kidney) at a dose of 25-200 mg/kg. bw d day.

Table 4. Effect of Maydis stigma (FMS) on organ weights in mice.

\begin{tabular}{ccccc}
\hline Group & Liver $(\mathbf{m g} / \mathbf{g})$ & Spleen $(\mathbf{m g} / \mathbf{g})$ & Lung $(\mathbf{m g} / \mathbf{g})$ & Kidney $(\mathrm{mg} / \mathbf{g})$ \\
\hline Control & $53.88 \pm 2.83$ & $4.60 \pm 1.14$ & $6.69 \pm 0.98$ & $12.81 \pm 2.18$ \\
Model & $55.15 \pm 3.59$ & $4.25 \pm 1.95$ & $6.07 \pm 0.51$ & $13.57 \pm 1.51$ \\
Dose of $25 \mathrm{mg} / \mathrm{kg} \cdot \mathrm{bw} \cdot$ day & $55.91 \pm 2.65$ & $3.91 \pm 1.38$ & $6.86 \pm 1.03$ & $13.22 \pm 1.38$ \\
Dose of $50 \mathrm{mg} / \mathrm{kg} \cdot \mathrm{bw} \cdot$ day & $54.06 \pm 2.72$ & $4.01 \pm 2.20$ & $6.95 \pm 0.88$ & $13.25 \pm 1.76$ \\
Dose of $100 \mathrm{mg} / \mathrm{kg} \cdot \mathrm{bw} \cdot$ day & $51.29 \pm 4.04$ & $4.13 \pm 1.85$ & $6.34 \pm 0.69$ & $12.78 \pm 1.58$ \\
Dose of 200 $\mathrm{mg} / \mathrm{kg} \cdot \mathrm{bw} \cdot$ day & $54.30 \pm 2.23$ & $3.72 \pm 1.66$ & $6.51 \pm 0.72$ & $13.04 \pm 1.91$ \\
Positive control & $52.94 \pm 3.28$ & $3.80 \pm 2.09$ & $6.30 \pm 0.50$ & $13.48 \pm 2.37$ \\
\hline
\end{tabular}

Values are mean \pm SD for 10 mice in each group.

\subsubsection{Effect of FMS on the Activity of T-SOD and the Content of MDA in Serum}

The lipid peroxidation process, which is triggered by free radicals, generates some final products of polyunsaturated fatty acid peroxidation in cells [26]. Malondialdehyde (MDA) is a frequently used parameter of lipid peroxidation [27]. Superoxide dismutase (SOD) is an essential antioxidant enzyme in the body, which can effectively scavenge the superoxide radical, and protect the body from oxidative stress [28].

Table 5 shows the activity of T-SOD and the content of MDA in the serum. As is shown in the table, the activity of T-SOD in model group is lower than that in control group $(p<0.01)$, and the content of MDA in the model group is higher than that in the control group $(p<0.01)$, which indicated that ethanol could cause oxidative damage to mice, and reduce the antioxidant capacity of mice serum.

Table 5. Effect of FSM on the activity of total superoxide dismutase (T-SOD), the content of malondialdehyde (MDA) in serum and the content of antioxidant, glutathione (GSH), protein carbonyl (PC) in liver tissue.

\begin{tabular}{|c|c|c|c|c|}
\hline Group & T-SOD (U/mL) & MDA (nmol/mL) & GSH (mg/gprot) & PC (nmol/mgprot) \\
\hline Control & $238.11 \pm 30.99^{a}$ & $7.23 \pm 1.17^{\mathrm{a}}$ & $14.25 \pm 0.92^{\mathrm{a}}$ & $3.02 \pm 1.10^{\mathrm{a}}$ \\
\hline Model & $134.47 \pm 33.38^{b}$ & $13.41 \pm 1.00^{b}$ & $10.34 \pm 1.15^{b}$ & $5.86 \pm 1.05^{b}$ \\
\hline Dose of $25 \mathrm{mg} / \mathrm{kg} \cdot \mathrm{bw} \cdot$ day & $185.97 \pm 21.77^{\mathrm{a}}$ & $8.64 \pm 1.24^{\mathrm{c}}$ & $13.42 \pm 1.33^{\mathrm{a}}$ & $4.22 \pm 0.66^{\mathrm{a}}$ \\
\hline Dose of $50 \mathrm{mg} / \mathrm{kg} \cdot \mathrm{bw} \cdot$ day & $192.76 \pm 17.51^{\mathrm{a}}$ & $6.95 \pm 0.97^{\mathrm{a}}$ & $14.34 \pm 1.66^{\mathrm{a}}$ & $3.87 \pm 0.83^{\mathrm{a}}$ \\
\hline Dose of $100 \mathrm{mg} / \mathrm{kg} \cdot \mathrm{bw} \cdot$ day & $200.38 \pm 13.30^{\mathrm{a}}$ & $7.26 \pm 0.76^{\mathrm{a}}$ & $16.10 \pm 2.05^{\mathrm{a}}$ & $2.98 \pm 0.66^{\mathrm{a}}$ \\
\hline Dose of $200 \mathrm{mg} / \mathrm{kg} \cdot \mathrm{bw} \cdot$ day & $231.53 \pm 28.31^{\mathrm{a}}$ & $6.71 \pm 0.65^{\mathrm{a}}$ & $18.01 \pm 1.41^{\mathrm{c}}$ & $1.44 \pm 0.69^{c}$ \\
\hline Positive control & $182.58 \pm 28.68^{a}$ & $10.08 \pm 0.59^{\mathrm{d}}$ & $16.08 \pm 1.14^{\mathrm{a}}$ & $2.36 \pm 1.00^{\mathrm{a}}$ \\
\hline
\end{tabular}

Values are mean \pm SD for 10 mice in each group. Different letters in the same column represent statistically significant differences $(p<0.05)$.

The results indicated that the activity of T-SOD in the model group is significantly lower than that in the dose groups $(p<0.01)$ and positive control group $(p<0.01)$, and the content of MDA in the model group is significant higher than that in the dose groups $(p<0.01)$ and positive control group $(p<0.01)$. Pre-treatment of mice with FMS could significantly protect, in a dose dependent manner, against T-SOD depletion and MDA increment induced by acute EtOH administration. In addition, compared with the model group, pre-treatment with vitamin $C$ was also found to significantly 
enhance the T-SOD activity and decrease the content of MDA. There are no significant differences of the enhancement of T-SOD activity between the positive control group and FMS dose groups. However, the reduction effects of the MDA content in FMS-treated groups were significantly higher compared to the positive control group. These results show that FMS prevents ethanol-induced T-SOD depletion and MDA increment in a dose-dependent manner.

\subsubsection{Effect of FMS on the Content of GSH and PC in Liver Tissue}

As an antioxidant, glutathione (GSH) can protect the cell from harmful effects of oxidative stress, and plays a key role in many diseases of aging and pathogenesis, such as cancer, Alzheimer's disease, Parkinson's disease, seizure, heart attack, diabetes, etc. [29,30]. The content of protein carbonyl (PC) is a widely used parameter to describe the level of oxidative damage to proteins, and reflects the damage in the cell induced by reactive oxygen species [31].

Table 5 lists the comparison of the content of GSH and PC among these groups in liver tissue. As shown in the table, the content of GSH in the model group is lower than that in control group $(p<0.01)$, and the content of PC in the model group is higher than that in control group $(p<0.01)$, which indicates that ethanol does cause oxidative damage to mice, and reduce the antioxidant capacity of mice liver tissue.

Compared with the model group, the content of GSH in the dose groups and positive control group is higher $(p<0.01)$, and the content of PC in the dose groups and positive control group is lower $(p<0.01)$. The results indicate that FMS and vitamin $C$ can significantly reverse the ethanol-diminished GSH content and diminish the protein oxidation induced by ethanol in the liver tissue. In addition, compared with the model group, pre-treatment of FMS at doses of 25, $50,100,200 \mathrm{mg} / \mathrm{kg}$. day could significantly increase the GSH content and decrease the PC content in liver tissue in ethanol-treated mice. Meanwhile, the GSH and PC content in livers of mice pre-treated with a dose of $200 \mathrm{mg} / \mathrm{kg}$. bw . day and positive control group were significantly different. This result indicates that FMS at a dose of $200 \mathrm{mg} / \mathrm{kg}$. bw. day has a higher protective effect against ethanol-induced GSH depletion and PC content increment than vitamin C.

In this study, oral administration of FMS at doses of $30 \mathrm{~g} / \mathrm{kg}$ did not cause the death of male and female mice, and there were no biologically significant adverse effects in mice after an observation time of 14 days. According to the results, we could draw the conclusion that the $\mathrm{LD}_{50}$ value for oral administration of FMS in male and female mice is higher than $30 \mathrm{~g} / \mathrm{kg}$. In the assays of in vitro antioxidant activity, FMS were found to show potent scavenging activity against DPPH and ABTS radical, and $\mathrm{IC}_{50}$ values were $50.73 \pm 0.65 \mu \mathrm{g} / \mathrm{mL}$ and $0.23 \pm 0.03 \mathrm{mg} / \mathrm{mL}$, respectively. However, the scavenging activity on DPPH and ABTS radical of FMS was weaker than vitamin C.

Furthermore, FMS at the tested doses $(25,50,100,200 \mathrm{mg} / \mathrm{kg}$. day) can significantly enhance total superoxide dismutase (T-SOD) activity, reduce malondialdehyde (MDA) content in the serum, increase glutathione (GSH) content, and lower protein carbonyl (PC) content in the liver tissue. The results showed that FMS exhibited a potent antioxidant activity in vivo, and the antioxidant activity of FMS was significantly better than that of vitamin C.

In recent years, some researches have proved that the extract of Maydis stigma possess potent antioxidant activity in vivo. It has been reported that the flavone glycoside isolated from the Maydis stigma has potent antioxidative and antiapoptotic activities, and it can significantly protect the cell against $\mathrm{H}_{2} \mathrm{O}_{2}$-induced neurotoxicity, which mediates by upregulating the expression of antioxidant enzymes, reduces the accumulation of ROS, and inhibits the damage of DNA [32]. NF-E2-related factor 2 (Nrf2) is a key transcription factor that can regulate expression of antioxidant enzymes and the anti-apoptosis gene. Another study pointed out that the ethanol extract of Maydis stigma can protect the cell against oxidative damage induced by radiation, and its antioxidant activity may be related to the up-regulation of Nrf2 [33]. In our study, the antioxidant activity of FMS in vivo was significantly better than in vitro when compared to vitamin $C$, which may be caused by the regulation of genes and proteins expression in the cell. Besides, FMS may be metabolized 
to compounds which possess potent antioxidant activity in vivo. However, the mechanism of its antioxidant activity is not yet clear.

\section{Experimental Section}

\subsection{Chemicals and Materials}

Maydis stigma was collected from corn fields in October 2014 in Jilin, China. 1,1-diphenyl-2picrylhydrazyl (DPPH), 2,2'-azinobis-(3-ethyl-benzthiazoline-6-sulphonate) (ABTS), total superoxide dismutase (T-SOD), malondialdehyde (MDA), glutathione (GSH), protein carbonyl (PC), total protein test kits were purchased from Nanjing Jiancheng Bioengineering Institute (Nanjing, China); All other chemicals and reagents were purchased locally and were of analytical grade.

\subsection{Experimental Animals}

Eight weeks old and weight of 25 to $30 \mathrm{~g}$ mice, with half male and half female were used for the test of in vivo antioxidant activity. Four weeks old and weight of 18 to $22 \mathrm{~g}$ mice, with half male and half female were used for the test of acute toxicity. Before the test, mice were reared for 7 days in the experimental environment by feeding common forages. All experimental procedures used in this study were approved by the ethics committee in this institute and all animal experiments were performed in accordance with the ethical standards laid down in the 1964 Declaration of Helsinki. The authors who performed experiments gave their informed consent prior to the study and followed "principles of laboratory animal care" (NIH publication No. 86-23, revised 1985).

\subsection{Extraction and Determination of Flavonoid Content}

The pulverised Maydis stigma ( $300 \mathrm{~g}$ ) was extracted with water at $80^{\circ} \mathrm{C}(9 \mathrm{~L}$ water, $1 \mathrm{~h}$ for the first time, $4.5 \mathrm{~L}$ water, $0.5 \mathrm{~h}$ for the second time). The extract was filtered through a Whatman No. 1 filter paper to remove the debris and the filtrate was then concentrated to $3 \mathrm{~L}$ with a rotary flash evaporator at $40^{\circ} \mathrm{C}$ under vacuum (RE-52A, Shanghai Yarong Biochemical Instruments Co. Shanghai, China). Then, the water extract of $M$. stigma was precipitated by the addition of anhydrous ethanol to a final concentration of $70 \%(v / v)$. The mixture was maintained overnight at room temperature. The supernatant was obtained by centrifugation ( $3500 \mathrm{rpm}, 15 \mathrm{~min}$ ), and then concentrated using a rotary flash evaporator and freeze dried to furnish the flavonoid rich extract from Maydis stigma (FMS).

A colorimetric aluminum chloride method was used for determination of the contents of flavonoid [34] with some modification. A dilute solution of FMS in methanol $(0.5 \mathrm{~mL}$ in $50 \mathrm{~mL})$ was separately mixed with $4.5 \mathrm{~mL}$ of methanol and $5.0 \mathrm{~mL}$ of $0.01-\mathrm{mol} / \mathrm{L}$ aluminum chloride in methanol. The reaction mixture remained at room temperature for $10 \mathrm{~min}$. Then, the absorbance of the reaction mixture was measured at $400 \mathrm{~nm}$ using an ultraviolet visible spectrophotometer (UV-2550, Shimadzu Corporation, Kyoto, Japan). The calibration curve was established by preparing rutin solutions at concentrations ranging from 0.005 to $0.125 \mathrm{mg} / \mathrm{mL}$ in methanol. The yield of the flavonoids was expressed as mg of rutin equivalents per gram of M. stigma on a dry weight basis. The purity of total flavonoids in the extracts of M. stigma was $10.45 \%$.

\subsection{Acute Toxicity in Mice}

The test of acute toxicity in mice was investigated by the method of Organization for Economic Cooperation and Development (OECD) Guidelines for Testing of Chemicals [35].

The mice ( 4 weeks old, weight of 18 to $22 \mathrm{~g}$ ) were randomly divided into 2 groups, which included the control group and experimented group, also each group had ten mice with half male and half female. Experimented groups were orally administered with solutions which were prepared by dissolving raw extracts of flavonoids from M. stigma at a dose of $10 \mathrm{~g} / \mathrm{kg}$ into the distilled water. Additionally, the control group was orally administered with the equivalent of distilled water. All the mice were orally administered with solutions or distilled water by oral gavage once every $8 \mathrm{~h}$ for 
consecutive $24 \mathrm{~h}$, and a maximum dose up to $30 \mathrm{~g} / \mathrm{kg}$ body weight. After administration for three times, mice of each group were observed for 14 days for clinical signs and mortality. The clinical signs includes: addition of body weight, food, and water consumption.

On day 14 on completion, all the animals were euthanized and blood samples were collected from mice orbit to separate and centrifuge blood serum under the condition of $5{ }^{\circ} \mathrm{C}, 2000 \mathrm{r} / \mathrm{min}$ for $15 \mathrm{~min}$. All the blood serum was stored at $-4{ }^{\circ} \mathrm{C}$ for standby. The following biochemical parameters were determined: glucose (GLU), alkaline phosphatase (ALP), alanine aminotransferase (ALT), aspartate aminotransferase (AST). Meanwhile, the main organs (heart, liver, spleen, lung, kidney, thymus, brain, bladder, uterus, testis, epididymis, seminal vesicle) of mice were quickly removed, dried with filter paper and weighed. Finally, the median lethal dose $\left(L_{50}\right)$ values were determined according to the test results.

\subsection{In Vitro Antioxidant Activity}

\subsubsection{DPPH Radical Scavenging Assay}

The antioxidant activity of scavenge DPPH radical species was investigated by the method of $\mathrm{Wu}$ et al. [36] with some modifications. The extracts of FMS were dissolved in ethanol at different concentrations $(20 \mu \mathrm{g} / \mathrm{mL}, 40 \mu \mathrm{g} / \mathrm{mL}, 60 \mu \mathrm{g} / \mathrm{mL}, 80 \mu \mathrm{g} / \mathrm{mL}, 100 \mu \mathrm{g} / \mathrm{mL})$. The $2.0 \mathrm{~mL}$ alcoholic solution of DPPH $(0.1 \mathrm{mmol} / \mathrm{L})$ was added to the $2.0 \mathrm{~mL}$ solution of sample with different concentrations of FMS, respectively. The mixture was reacted at room temperature for 30 min under strict exclusion of light. After that, the absorbance was measured at $517 \mathrm{~nm}$, with ethanol as blank control. Also, vitamin C was used as a reference standard.

DPPH radical scavenging activity was calculated using formula:

$$
\operatorname{RSA}(\%)=\left[\left(\mathrm{A}_{\mathrm{c}}-\mathrm{A}_{\mathrm{t}}\right) / \mathrm{A}_{\mathrm{c}}\right] \times 100
$$

where $A_{c}$ and $A_{t}$ is the absorbance of pure DPPH and the absorbance of DPPH in the sample, respectively. The result was expressed as the half maximal inhibitory concentration $\left(\mathrm{IC}_{50}\right)$ of FMS.

\subsubsection{ABTS Radical Scavenging Assay}

The antioxidant activity of scavenge ABTS radical species was investigated by the method described by Antolovich et al. [37] with some modifications. The $5.0 \mathrm{~mL}$ ABTS solution $(7.0 \mathrm{mmol} / \mathrm{L})$ was mixed with $88 \mu \mathrm{L}$ potassium persulfate $\left(\mathrm{K}_{2} \mathrm{~S}_{2} \mathrm{O}_{8}\right)$ solution $(140 \mathrm{mmol} / \mathrm{L})$, and the mixture was kept at room temperature for $15 \mathrm{~h}$ under strict exclusion of light. After that, the solution was diluted with distilled water to obtain an absorbance of $0.7 \pm 0.02$ units at $734 \mathrm{~nm}$ at a temperature of $30^{\circ} \mathrm{C}$. Then, to perform the ABTS radical scavenging assay, the $3 \mathrm{~mL}$ solution of ABTS was added to the $200 \mu \mathrm{L}$ FMS solution at various concentrations $(0.1 \mathrm{mg} / \mathrm{mL}, 0.5 \mathrm{mg} / \mathrm{mL}, 1.0 \mathrm{mg} / \mathrm{mL}, 1.5 \mathrm{mg} / \mathrm{mL}$, $2.0 \mathrm{mg} / \mathrm{mL}, 2.5 \mathrm{mg} / \mathrm{mL}, 3.0 \mathrm{mg} / \mathrm{mL}$ ), respectively. The mixture was reacted at room temperature for $1 \mathrm{~h}$ under strictly exclusion of light. After that, the absorbance was measured at $734 \mathrm{~nm}$, with solvent as blank control. Additionally, vitamin $\mathrm{C}$ was used as a positive control.

ABTS radical scavenging activity was calculated using formula:

$$
\operatorname{RSA}(\%)=\left[\left(\mathrm{A}_{\mathrm{c}}-\mathrm{A}_{\mathrm{t}}\right) / \mathrm{A}_{\mathrm{c}}\right] \times 100
$$

where $A_{c}$ and $A_{t}$ was the absorbance of control and the absorbance of sample or standard, respectively. The result was expressed as the half maximal inhibitory concentration $\left(\mathrm{IC}_{50}\right)$ of FMS.

\subsection{In Vivo Antioxidant Activity in Mice}

All in vivo antioxidant activity experiments were conducted according to the Method for the Assessment of Antioxidative Function which was issued by the China Food and Drug Administration. The mice ( 8 weeks old, weight of 25 to $30 \mathrm{~g}$, female) were randomly divided into 
7 groups, which included the control group, model group, positive control group, FMS-treated groups $(25,50,100,200 \mathrm{mg} / \mathrm{kg} \cdot \mathrm{bw} \cdot$ day), and each group had ten mice. Four FMS-treated groups were orally administered with solutions which were prepared by dissolving raw extracts of flavonoids from M. stigma with doses of $25,50,100,200 \mathrm{mg} / \mathrm{kg} \cdot \mathrm{bw}$. day into the distilled water, respectively. The positive control group was orally administered with solutions by dissolving vitamin $\mathrm{C}$ with doses of $200 \mathrm{mg} / \mathrm{kg}$. bw . day into the distilled water. The model group and control group were orally administered with the equivalent amount of distilled water per day.

After 30 days, all the animals were fasted overnight. Then all mice except for the control group were orally perfused $50 \%$ ethanol with a dose of $12 \mathrm{~mL} / \mathrm{kg}$ body weight to make oxidative damage mould [38]. After $6 \mathrm{~h}$, blood samples were collected into a heparinized Eppendorf tube from a mice orbit to separate and centrifuge blood serum under condition of $5{ }^{\circ} \mathrm{C}, 2000 \mathrm{r} / \mathrm{min}$ for $15 \mathrm{~min}$. After that, the mice were killed and the liver, lung, kidney, and spleen of mice were dissected, dried with filter paper, and weighed. All organs were dried with filter paper before weighing. The livers were homogenized in ice-cold $10 \%$ PBS $(0.02 \mathrm{~mol} / \mathrm{L}, \mathrm{pH} 7.2)$ under centrifugation condition of $5{ }^{\circ} \mathrm{C}, 2500 \mathrm{r} / \mathrm{min}$ for $10 \mathrm{~min}$ to collect a clear supernatant liquid. The serum total superoxide dismutase (T-SOD) activity, malondialdehyde (MDA) content, liver tissue glutathione (GSH) content, and protein carbonyl (PC) content in tissue supernatants were chosen as indices to observe the influence of FMS on the antioxidant ability of ethanol oxidation to damage model mice. All the experiments were carried out according to the instructions of commercial kits purchased from the Nanjing Jiancheng Bioengineering Institute (Nanjing, China).

\subsection{Statistical Analysis}

Statistical analysis was conducted using the one-way analysis of variance (ANOVA) with the statistical program SPSS 19.0. The results were expressed as mean \pm standard deviation in triplicate. Significant differences were set at $p<0.05$.

\section{Conclusions}

In conclusion, although the flavonoids extracted from $M$. stigma might have an anti-aging effect because of their potent antioxidant activity, the mechanism of the antioxidant activity is still unclear and whether it is effective for the human body is still unknown. Therefore, additional studies will be necessary to verify the mechanism of antioxidant activity and the toxicological effect on the human body. In view of the potential use of $M$. stigma in the field of the food and drug industry, the flavonoids extracted from M. stigma as a natural antioxidant, can be utilized for preventing diseases caused by oxidative stress, and have a broad prospect of application and development.

Acknowledgments: This work was supported by the Scientific Research Project in the Science and Technology Development Plan of Jilin Province (Grant No. 20130303050NY and 20150311044YY) and the Science and Technology Program of Jilin Institute of Chemical Technology (Grant No. 2015037).

Author Contributions: Ke-Zheng Peng and Xiudong Yang performed the experiments; The works were designed and supervised by Hong-Li Zhou. Shu-Xia Pan analyzed the data.

Conflicts of Interest: The authors declare no conflict of interest.

\section{References}

1. Ramessar, K.; Sabalza, M.; Capell, T.; Christou, P. Maize plants: An ideal production platform for effective and safe molecular pharming. Plant. Sci. 2008, 174, 409-419. [CrossRef]

2. Naqvi, S.; Ramessar, K.; Farré, G.; Sabalza, M.; Miralpeix, B.; Twyman, R.M.; Capell, T.; Zhu, C.; Christou, P. High-value products from transgenic maize. Biotechnol. Adv. 2011, 29, 40-53. [CrossRef] [PubMed]

3. Chen, S.; Chen, H.; Tian, J.; Wang, Y.; Xing, L.; Wang, J. Chemical modification, antioxidant and $\alpha$-amylase inhibitory activities of corn silk polysaccharides. Carbohydr. Polym. 2013, 98, 428-437. [CrossRef] [PubMed]

4. Liu, J.; Lin, S.; Wang, Z.; Wang, C.; Wang, E.; Zhang, Y.; Liu, J. Supercritical fluid extraction of flavonoids from Maydis stigma and its nitrite-scavenging ability. Food Bioprod. Process. 2011, 89, 333-339. [CrossRef] 
5. Abdel-Wahab, S.M.; El-Tanbouly, N.D.; Kassem, H.A.; Mohamed, E.A. Phytochemical and biological study of corn silk (styles and stigmas of Zea mays L.). Bull. Fac. Pharm. 2002, 40, 93-102.

6. Du, J.; Xu, Q.T. Study on antipyretic choleretic effect and acute toxicity of Stigma maydis polysaccharide. Lishizhen Med. Mater. Med. Res. 2007, 1, 75-77. (In Chinese).

7. Liu, J.; Wang, C.; Wang, Z.; Zhang, C.; Lu, S.; Liu, J. The antioxidant and free-radical scavenging activities of extract and fractions from corn silk (Zea mays L.) and related flavone glycosides. Food Chem. 2011, 126, 261-269. [CrossRef]

8. Maksimović, Z.; Malenčić, Đ.; Kovačević, N. Polyphenol contents and antioxidant activity of Maydis stigma extracts. Bioresour. Technol. 2005, 96, 873-877. [CrossRef] [PubMed]

9. Alam, E. Evaluation of antioxidant and antibacterial activities of Egyptian Maydis stigma (Zea mays hairs) rich in some bioactive constituents. J. Am. Sci. 2011, 7, 726-729.

10. Wang, G.Q.; Xu, T.; Bu, X.M.; Liu, B.Y. Anti-inflammation effects of corn silk in a rat model of carrageenin-induced pleurisy. Inflammation 2012, 35, 822-827. [CrossRef] [PubMed]

11. Ebrahimzadeh, M.A.; Mahmoudi, M.; Ahangar, N.; Ehteshami, S.; Ansaroudi, F.; Nabavi, S.F.; Nabavi, S.M. Antidepressant activity of corn silk. Pharmacol. Online 2009, 3, 647-652.

12. Hu, Q.L.; Zhang, L.J.; Li, Y.N.; Ding, Y.J.; Li, F.L. Purification and anti-fatigue activity of flavonoids from corn silk. Int. J. Phys. Sci. 2010, 5, 321-326.

13. Guo, J.; Liu, T.; Han, L.; Liu, Y. The effects of corn silk on glycaemic metabolism. Nutr. Metab. $2009,6$. [CrossRef] [PubMed]

14. Hasanudin, K.; Hashim, P.; Mustafa, S. Corn silk (Maydis stigma) in healthcare: A phytochemical and pharmacological review. Molecules 2012, 17, 9697-9715. [CrossRef] [PubMed]

15. Masuoka, N.; Matsuda, M.; Kubo, I. Characterisation of the antioxidant activity of flavonoids. Food Chem. 2012, 131, 541-545. [CrossRef]

16. Pietta, P.G. Flavonoids as antioxidants. J. Nat. Prod. 2000, 63, 1035-1042. [CrossRef] [PubMed]

17. Wang, S.Y.; Chen, H.; Camp, M.J.; Ehlenfeldt, M.K. Flavonoid constituents and their contribution to antioxidant activity in cultivars and hybrids of rabbiteye blueberry (Vaccinium ashei Reade). Food Chem. 2012, 132, 855-864. [CrossRef]

18. Lou, S.N.; Hsu, Y.S.; Ho, C.T. Flavonoid compositions and antioxidant activity of calamondin extracts prepared using different solvents. J. Food Drug Anal. 2014, 22, 290-295. [CrossRef]

19. Karimi, E.; Oskoueian, E.; Hendra, R.; Jaafar, H.Z. Evaluation of Crocus sativus L. stigma phenolic and flavonoid compounds and its antioxidant activity. Molecules 2010, 15, 6244-6256. [CrossRef] [PubMed]

20. Li, H.; Luo, S.; Su, J.; Ke, H.; Wang, W.; Yang, B. Optimization of Extraction Conditions for Flavonoid Composition and Antioxidant Activity of Radix scutellariae. Anal. Lett. 2015, 48, 1234-1244. [CrossRef]

21. El-Ghorab, A.; El-Massry, K.F.; Shibamoto, T. Chemical composition of the volatile extract and antioxidant activities of the volatile and nonvolatile extracts of Egyptian corn silk (Zea mays L.). J. Agric. Food Chem. 2007, 55, 9124-9127. [CrossRef] [PubMed]

22. Ren, S.C.; Qiao, Q.Q.; Ding, X.L. Antioxidative activity of five flavones glycosides from Corn silk (Stigma maydis). Czech J. Food Sci. 2013, 31, 148-155.

23. Hu, Q.L.; Deng, Z.H. Protective effects of flavonoids from corn silk on oxidative stress induced by exhaustive exercise in mice. Afr. J. Biotechnol. 2011, 10, 3163-3167.

24. Walum, E. Acute oral toxicity. Environ. Health Perspect. 1998, 106, 497-503. [CrossRef] [PubMed]

25. Mabeku, L.B.K.; Beng, V.P.; Kouam, J.; Essame, O.; Etoa, F.X. Toxicological evaluation of ethyl acetate extract of Cylicodiscus gabunensis stem bark (Mimosaceae). J. Ethnopharmacol. 2007, 111, 598-606. [CrossRef] [PubMed]

26. Jin, S.L.; Yin, Y.G. In vivo antioxidant activity of total flavonoids from indocalamus leaves in aging mice caused by D-galactose. Food Chem. Toxicol. 2012, 50, 3814-3818. [CrossRef] [PubMed]

27. Nielsen, F.; Mikkelsen, B.B.; Nielsen, J.B.; Andersen, H.R.; Grandjean, P. Plasma malondialdehyde as biomarker for oxidative stress: Reference interval and effects of life-style factors. Clin. Chem. 1997, 43, 1209-1214. [PubMed]

28. MatÉs, J.M.; Pérez-Gómez, C.; de Castro, I.N. Antioxidant enzymes and human diseases. Clin. Biochem. 1999, 32, 595-603. [CrossRef]

29. Pompella, A.; Visvikis, A.; Paolicchi, A.; de Tata, V.; Casini, A.F. The changing faces of glutathione, a cellular protagonist. Biochem. Pharmacol. 2003, 66, 1499-1503. [CrossRef] 
30. Wu, G.; Fang, Y.Z.; Yang, S.; Lupton, J.R.; Turner, N.D. Glutathione metabolism and its implications for health. J. Nutr. 2004, 134, 489-492. [PubMed]

31. Pradeep, A.R.; Ramchandraprasad, M.V.; Bajaj, P.; Rao, N.S.; Agarwal, E. Protein carbonyl: An oxidative stress marker in gingival crevicular fluid in healthy, gingivitis, and chronic periodontitis subjects. Contemp. Clin. Dent. 2013, 4, 27-31. [CrossRef] [PubMed]

32. Bai, H.; Hai, C.X.; Xi, M.M.; Liang, X.; Liu, R. Protective effect of maize silks (Maydis stigma) ethanol extract on radiation-induced oxidative stress in mice. Plant Foods Hum. Nutr. 2010, 65, 271-276. [CrossRef] [PubMed]

33. Choi, D.J.; Kim, S.L.; Choi, J.W.; Park, Y.I. Neuroprotective effects of corn silk maysin via inhibition of H2O2-induced apoptotic cell death in SK-N-MC cells. Life Sci. 2014, 109, 57-64. [CrossRef] [PubMed]

34. Chang, C.; Yang, M.; Wen, H.; Chern, J. Estimation of total flavonoid content in propolis by two complementary colorimetric methods. J. Food Drug Anal. 2002, 10, 178-182.

35. Wilhelm, K.P.; Maibach, H.I. OECD guidelines for testing of chemicals. In Dermatoxicology, 7th ed.; CRC Press: Boca Raton, FL, USA, 2008; pp. 303-305.

36. Wu, P.; Ma, G.; Li, N.; Deng, Q.; Yin, Y.; Huang, R. Investigation of in vitro and in vivo antioxidant activities of flavonoids rich extract from the berries of Rhodomyrtus tomentosa (Ait.) Hassk. Food Chem. 2015, 173, 194-202. [CrossRef] [PubMed]

37. Antolovich, M.; Prenzler, P.D.; Patsalides, E.; McDonald, S.; Robards, K. Methods for testing antioxidant activity. Analyst 2002, 127, 183-198. [CrossRef] [PubMed]

38. Hoek, J.B.; Pastorino, J.G. Ethanol, oxidative stress, and cytokine-induced liver cell injury. Alcohol 2002, 27, 63-68. [CrossRef]

Sample Availability: Samples of the flavonoid-rich extract from Maydis stigma are available from the authors.

(C) 2015 by the authors; licensee MDPI, Basel, Switzerland. This article is an open access article distributed under the terms and conditions of the Creative Commons by Attribution (CC-BY) license (http:/ / creativecommons.org/licenses/by/4.0/). 